\title{
Two new species of hylid frogs, genus Osteocephalus, from Amazonian Ecuador
}

\author{
Karl-Heinz Jungfer ${ }^{1}$, Santiago Ron ${ }^{2}$, Robert Seipp ${ }^{3}$, Ana Almendáriz ${ }^{4}$ \\ ${ }^{1}$ Panoramastr. 14, 74405 Gaildorf, Germany \\ ${ }^{2}$ Departamento de Ciencias Biológicas, Pontifica Universidad Católica del Ecuador, Apartado 17-01-2184, \\ Quito, Ecuador \\ ${ }^{3}$ Forschungsinstitut Senckenberg, Senckenberganlage 25, 60325 Frankfurt am Main, Germany \\ ${ }^{4}$ Escuela Politécnica Nacional, Departamento de Ciencias Biológicas, Apartado 25759, Quito, Ecuador
}

\begin{abstract}
We describe two new species of treefrogs of the genus Osteocephalus from primary forests in northeastern Amazonian Ecuador. One is a small to medium-sized species without or with only few flat dorsal tubercles in males and a large light subocular area. Tadpoles assigned to this species were found in a bromeliad and had eaten fertilized frog eggs, most likely provided by the parents. The second species is small to medium, has a smooth dorsum both in males and females and no light subocular spot.
\end{abstract}

Resumen. Describimos dos nuevas especies de ranas arborícolas del género Osteocephalus de bosques primarios en la Amazonía nororiental en Ecuador. La primera especie es de pequeña a mediana sin o con pocos tubérculos dorsales aplanados en machos y una mancha clara subocular grande. Los renacuajos asignados a esta especie fueron encontrados en una bromelia y habían comido huevos de rana fertilizados, probablemente proveídos por la madre. La segunda especie es de pequeña a mediana, tiene dorso liso tanto en hembras como en machos y no tiene manchas suboculares claras.

\section{Introduction}

Frogs of the genus Osteocephalus are medium-sized to large treefrogs widely distributed throughout the Amazon Basin, Guiana, and parts of the Atlantic Forest of southeastern South America. Therefore, and because they live almost exclusively in primary forest, they form an important constituent of the frog fauna of intact rainforests. All of them are arboreal. While most have to descend to pools and streams for reproduction, there are also species that breed in phytotelmata in the higher stratum of trees and are not necessarily encountered on the ground (Jungfer and Schiesari, 1995). This, and the fact that several species of Osteocephalus are more or less tan and largely resemble each other, may be 
the reason why there are undescribed species in areas that are otherwise considered to be herpetologically well known.

The genus was reviewed in 1971 by Trueb and Duellman. Jungfer and Schiesari (1995) listed the eight species recognized then. Three more were resurrected or described subsequently by Duellman and Mendelson (1995) and Gorzula and Señaris (1996). Seven species have been reported from Ecuador: Osteocephalus buckleyi (Boulenger, 1882), O. cabrerai (Cochran and Goin, 1970), O. leprieurii (Dumèril and Bibron, 1841), O. planiceps (Cope, 1874), O. taurinus Steindachner, 1862, and O. verruciger (Werner, 1901) (Trueb and Duellman, 1971; Coloma, 1991; Ron, 1998). The seventh species, O. yasuni, from the Amazon Basin of Ecuador and Peru, was described recently (Ron and Pramuk, 1999). During the last few years we independently collected two new species of canopy-dwelling Osteocephalus. Both may have elapsed the attention of other workers either because they live high up in trees or they are morphologically similar to the other species, especially in preservative. The aim of the present paper is to gather our data and describe the two new species. As in O. oophagus (Jungfer and Schiesari, 1995), both species add unusual characters to the known features of the genus as defined by Trueb and Duellman (1971) and altered by Duellman and Hoogmoed (1992), demonstrating that a thorough review of the genus is needed, which is, however, beyond the scope of this paper. In males of both new species the vocal sacs are single and median, nuptial pads are absent, and there is no sexual dimorphism in the dorsal skin structure.

\section{Materials and methods}

Measurements follow Duellman (1970), except for head length (Heyer et al., 1990). They were taken by the senior author, except in QCAZ 8137 and 8806 (SR). Webbing formula is that of Savage and Heyer (1967), as modified by Myers and Duellman (1982). Museum abbreviations used are: EPN: Escuela Politécnica Nacional, Herpetología, Quito; MHNG: Muséum d'Histoire naturelle, Genève; QCAZ: Museo de Zoología Universidad Católica del Ecuador, Quito; SMF: Senckenberg-Museum, Frankfurt am Main; ZFMK: Zoologisches Forschungsinstitut und Museum Alexander Koenig, Bonn.

Calls were recorded with a Sony WM D6C tape recorder in combination with a Sennheiser ME 66 directional microphone. Sound analysis was made using Canary 1.2 software (Cornell University) on a Macintosh computer. The spectrogram was produced at a sample rate of $22 \mathrm{kHz}$ and an FFT size of 256 points.

Osteocephalus deridens n. sp. (fig. la-c, 2)

Holotype. EPN-H 6655, an adult female collected by K.-H. Jungfer on 26 December 1997 at Estación Biológica Jatun Sacha, (01 04'S; 77³6'W), a reserve about 8 km E Puerto Misahuallí, Provincia Napo, Ecuador, 450 m a.s.1. 

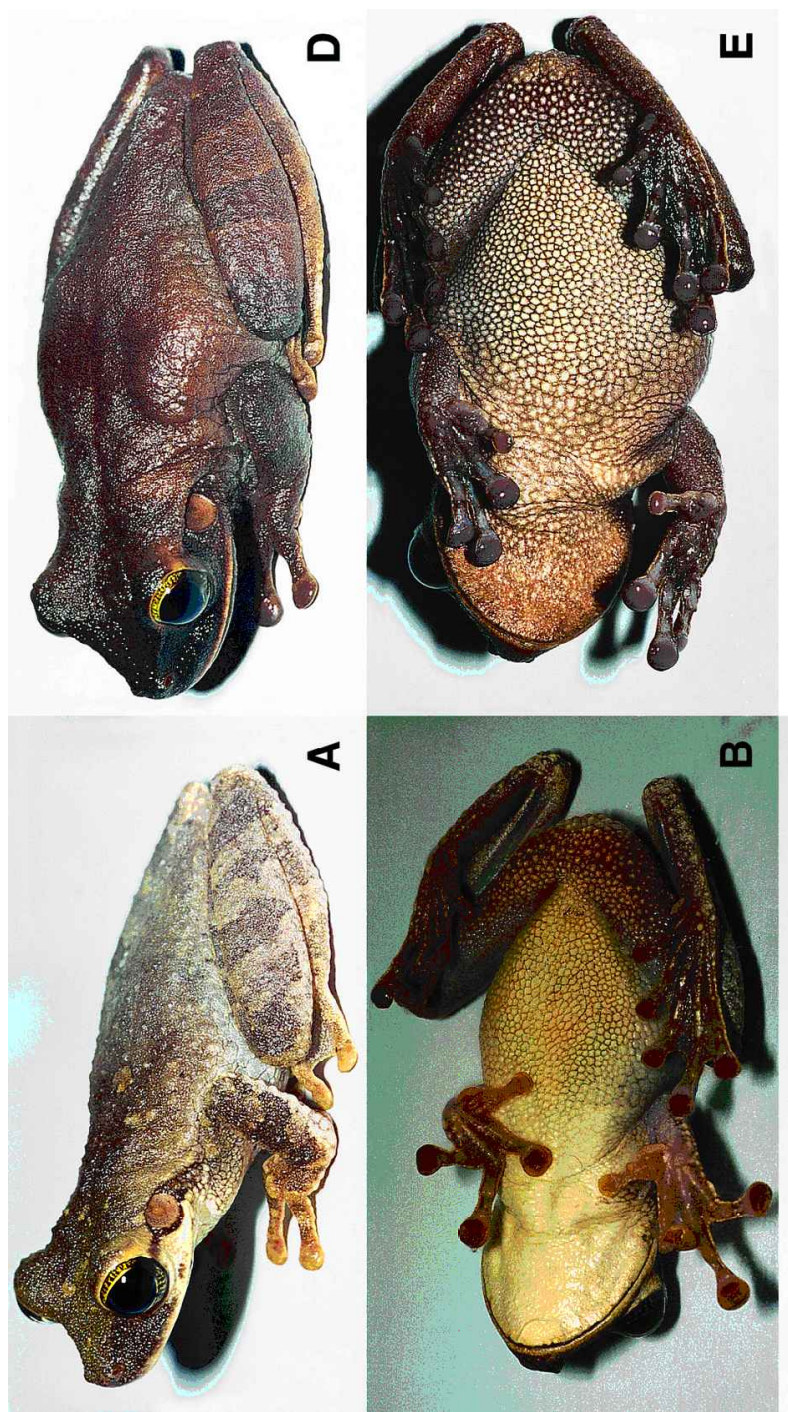

离

灵

$\ddot{0}$ वे

苍 폴

के ए

핍

잉

ฮี

ป

कू त

茍

$\ddot{\oplus}$

च

胥

可

늘

Z

.

过

ठ

D

ปึ่

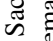

$\Xi$

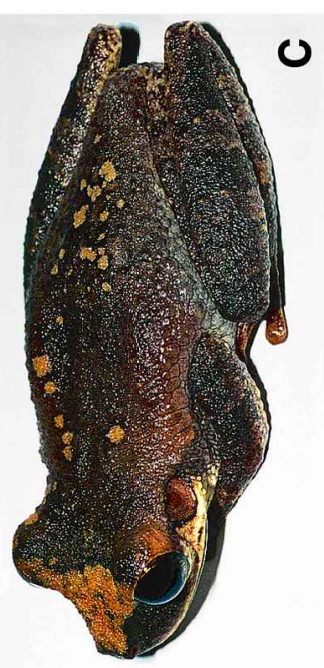

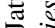

ำ

$\exists$

छ

in

ำ ํㅗㄹ

$+\frac{1}{>}$

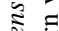

ป

(1)

$\circ$.

元

곤

8.

0

ธัँ

눙

远

递

总吉

Z.

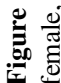




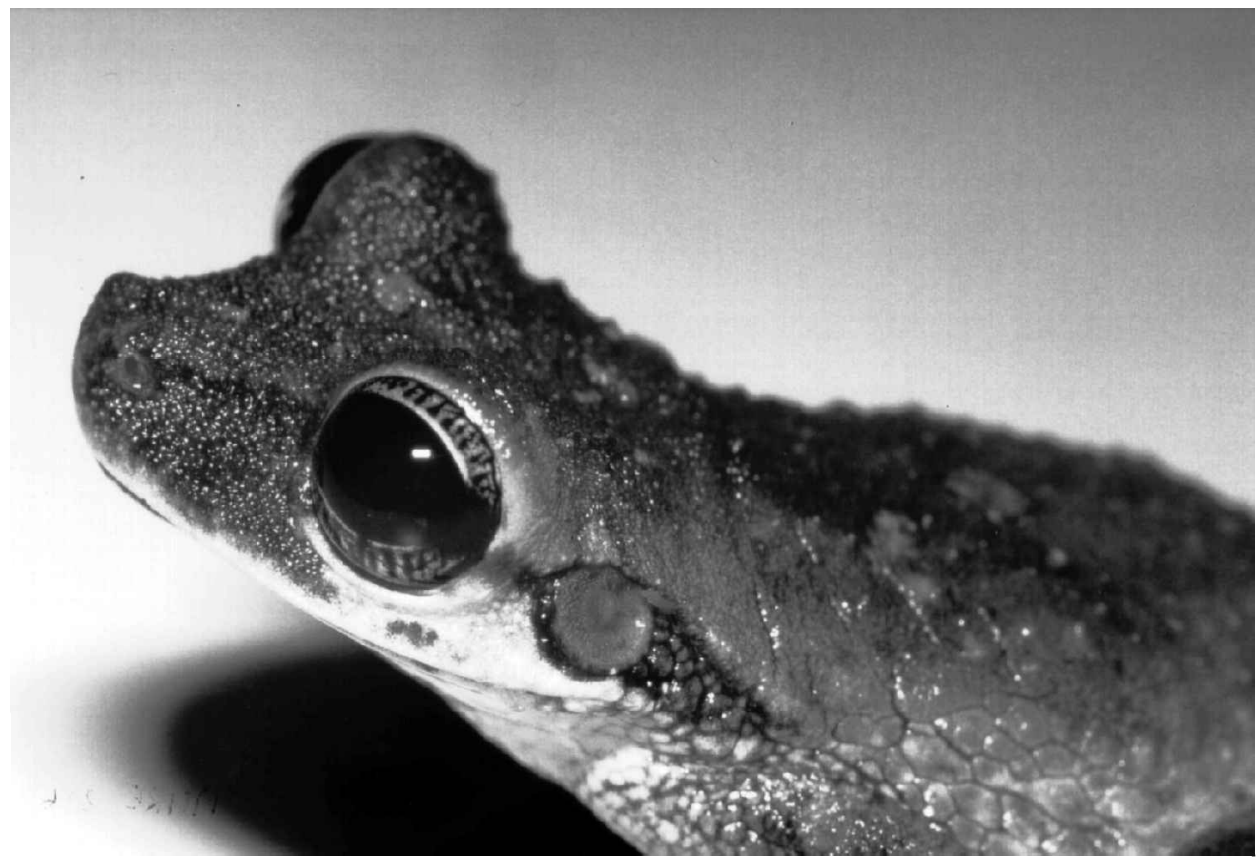

Figure 2. Head of $O$. deridens, female, $50 \mathrm{~mm}$, from Jatun Sacha, Ecuador.

Table 1. Measurements of Osteocephalus deridens. HL: head length; HW: head width; TD: tympanum diameter; ED: eye diameter; TL: tibia length; FL: foot length; ID: internarial distance; EN: distance from eye to nostril.

\begin{tabular}{lcccccccccc}
\hline No. & sex & SVL & HL & HW & ED & TD & TL & FL & ID & EN \\
\hline SMF 78743 & f & 50.6 & 18.3 & 17.4 & 5.7 & 3.5 & 28.6 & 33.5 & 4.1 & 5.0 \\
EPN H-6656 & f & 50.2 & 16.8 & 16.5 & 5.5 & 3.3 & 27.7 & 33.7 & 4.0 & 4.9 \\
EPN-H 6655 & f & 48.5 & 17.3 & 17.0 & 5.9 & 3.6 & 25.1 & 30.9 & 3.8 & 4.6 \\
ZFMK 68659 & f & 46.0 & 16.1 & 15.3 & 5.5 & 3.4 & 26.3 & 30.3 & 3.6 & 4.7 \\
SMF 78742 & f & 43.7 & 15.2 & 14.7 & 4.8 & 3.0 & 26.9 & 30.4 & 3.3 & 4.2 \\
QCAZ 12556 & m & 34.9 & 12.5 & 11.7 & 4.7 & 2.7 & 18.1 & 21.9 & 2.8 & 2.8 \\
\hline
\end{tabular}

Paratypes. Five specimens: SMF 78742, 78743, EPN H-6656, adult females collected by K.-H. Jungfer, all from the type locality. ZFMK 68659, an adult female collected by R. Perez, from Aliñahuí, $5 \mathrm{~km}$ W Ahuano, Provincia Napo, Ecuador. QCAZ 12556 from Yasuní Scientific Research Station ( $76^{\circ} 24^{\prime} 19^{\prime \prime}$ W; 0040'32"S), Provincia Napo, a male collected by K.-H. Jungfer and O. Piskurek.

Diagnosis. A small to medium sized species of the genus with females reaching $50.6 \mathrm{~mm}$ and males $34.9 \mathrm{~mm}$ snout-vent length (SVL). Dorsum of females smooth or with few scattered flat tubercles, smooth in males. Skin on flanks shagreened. Webbing on hand reaching proximal level of antepenultimate subarticular tubercle on inner edge of third 

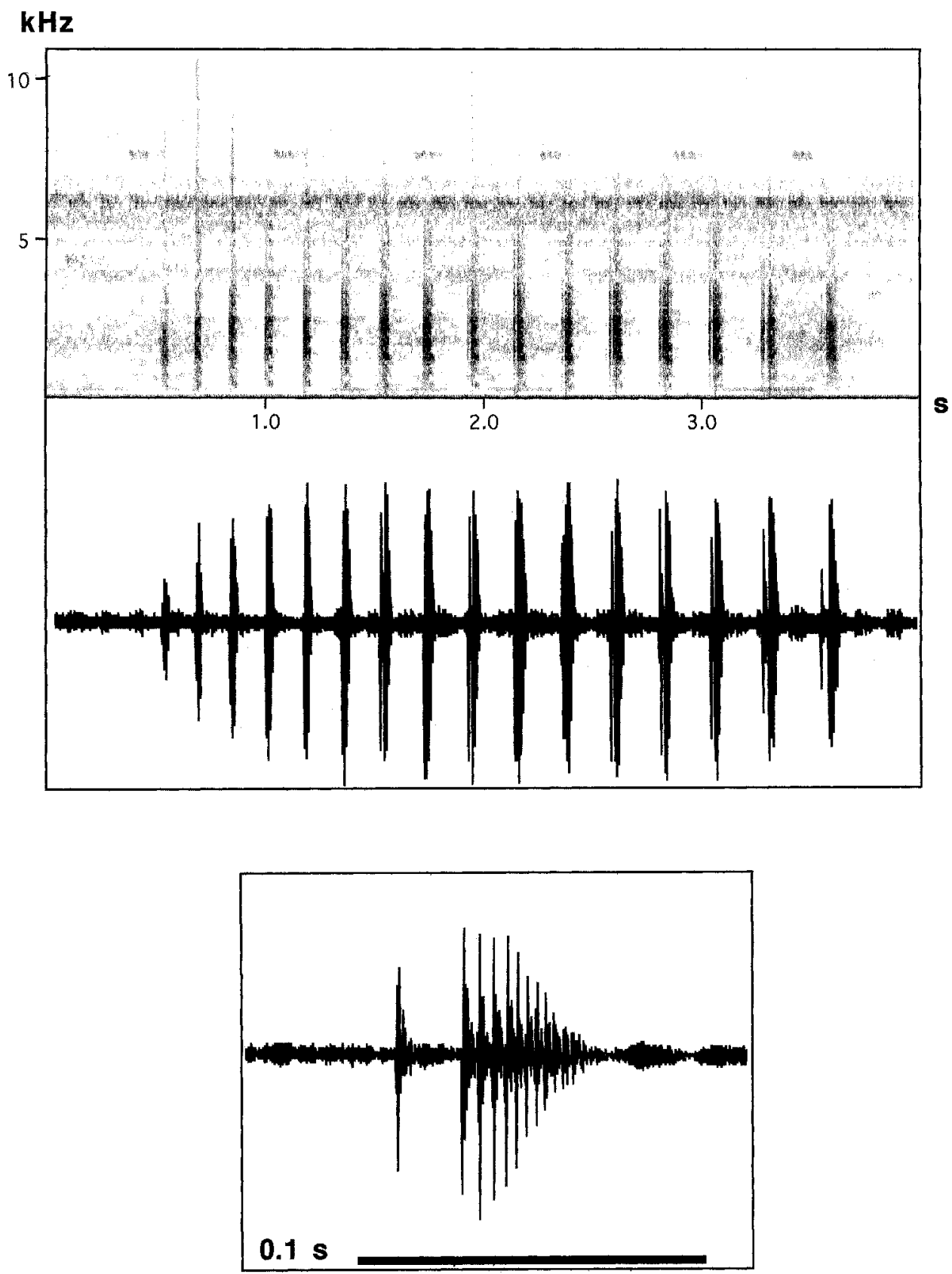

Figure 3. Advertisement call of Osteocephalus deridens recorded at Jatun Sacha on 14 August 1995 at $23.7^{\circ} \mathrm{C}$. Above: sound spectrogram; middle: corresponding oscillogram of complete call; below: oscillogram of note 14 . 


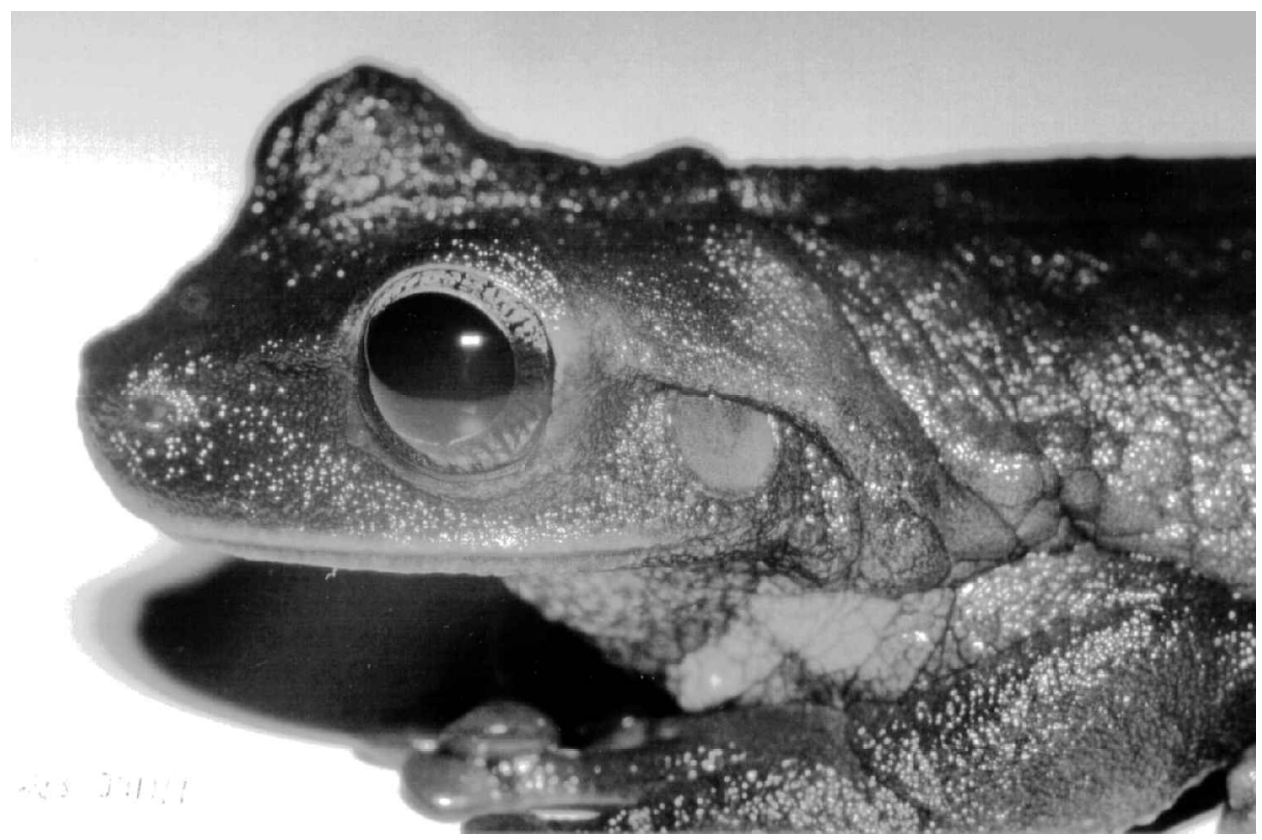

Figure 4. Head of $O$. fuscifacies, female, $53 \mathrm{~mm}$, from Selva Viva, Provincia Napo, Ecuador.

Table 2. Measurements of Osteocephalus fuscifacies. See table 1 for abbreviations.

\begin{tabular}{lcccccccccc}
\hline No. & sex & SVL & HL & HW & ED & TD & TL & FL & ID & EN \\
\hline ZFMK 68660 & $\mathrm{f}$ & 53.2 & 19.2 & 19.7 & 7.7 & 3.3 & 27.5 & 34.7 & 4.2 & 5.4 \\
MHNG 2366.73 & $\mathrm{m}$ & 45.6 & 15.8 & 14.7 & - & 2.8 & 22.9 & 29.1 & 3.6 & 4.2 \\
EPN-H 6657 & $\mathrm{m}$ & 44.8 & 16.2 & 16.0 & 5.5 & 2.8 & 20.9 & 26.1 & 3.5 & 3.8 \\
QCAZ 8137 & $\mathrm{m}$ & 42.6 & 15.1 & 15.7 & 4.6 & 2.8 & 22.0 & 17.5 & 3.9 & 5.2 \\
EPN-H 4775 & $\mathrm{m}$ & 42.2 & 15.2 & 15.2 & 4.5 & 3.0 & 22.7 & 29.9 & 3.5 & 4.1 \\
QCAZ 8806 & $\mathrm{m}$ & 41.1 & 14.7 & 15.2 & 4.4 & 2.7 & 22.0 & 15.8 & 3.4 & 4.1 \\
EPN-H 4774 & $\mathrm{m}$ & 39.2 & 14.4. & 14.5 & 4.2 & 2.6 & 21.1 & 26.5 & 3.5 & 3.8 \\
MHNG 2373.91 & $\mathrm{m}$ & 38.3 & 14.4 & 13.3 & 4.3 & 2.8 & 21.4 & 25.5 & 3.2 & 4.0 \\
\hline
\end{tabular}

finger. Dorsal colour light or dark tan, with or without irregular darker or lighter tan markings. Venter creamy white without markings. A broad creamy white subocular spot. Flanks tan with or without darker or lighter markings. Dentigerous processes of prevomers angular, the prevomerine teeth forming slightly curved or straight rows. Of the dorsal roofing bones of the skull only the nasals are very slightly exostosed posterolaterally, indicating lack of co-ossification or almost so (visible in EPN-H 6656).

Comparisons. Osteocephalus deridens can be distinguished from other species in the genus from the northwestern Amazon Basin and northern South America by the following features (those of $O$. deridens in parentheses): Males of O. elkejungingerae (Henle, 1981), 
O. leprieurii, O. taurinus and $O$. verruciger have a warty dorsum with spinous tubercles (smooth in $O$. deridens). Osteocephalus taurinus furthermore is much larger, up to $84.6 \mathrm{~mm}$ in males (34.9); O.planiceps (fig. 5a) is also larger, up to $65.9 \mathrm{~mm}$ in males, has a more pronounced canthus rostralis and angular prevomerine patches (straight); O. buckleyi and $O$. cabrerai have a row of tubercles on the tarsus and some supraorbital tubercles (lacking); an unnamed species from Peru (Rodríguez and Duellman, 1994; Duellman and Mendelson, 1995) has white bones (green); O. oophagus has more webbing on the hand and lacks or only has a faint light subocular spot (broad light spot present); O. fuscifacies (described below) lacks a subocular spot, $O$. yasuni (fig. 5b) has yellow ventral colouration (creamy white), white bones (green) and irregular black reticulation of the iris (black lines radiating from the iris), and O. ayarzaguenai Gorzula and Señaris, 1996, has red webbing between the toes (reddish $\tan$ ).

Description of holotype. Adult female of $48.5 \mathrm{~mm}$ SVL. Head wider than body and slightly longer than wide. Head dorsally slightly concave. Canthus rostralis straight, elevated and angular. Loreal region concave. An elevated ridge (underlying pars facialis of maxillary) from under the nostril to subocular area (not visible in live specimen). Snout rounded in lateral aspect and truncate in dorsal view. Dentigerous processes of prevomers in between choanae, reaching slightly posterior to choanae, in contact with each other, angular, the prevomerine teeth forming curving arches standing obliquely towards each other.

Dermal fold curving posterior to midlevel of eye above the tympanum to an area above the insertion of the arm at mouth level. Tympanum conspicuous, round, diameter about $60 \%$ of that of the eye. Axillary membrane absent. Dorsum with only a few flat tubercles. Laterally smooth, shagreened posterior to insertion of the arm. Throat finely granular. Chest, belly and proximal 2/3 of ventral surfaces of thigh granular. Vent opening covered by faint anal flap, situated at upper level of thighs. Subanal and bordering proximal thigh area covered with numerous flat tubercles.

Arms smooth, except for a row of small, low tubercles along the ventrolateral edge of forearm and fourth finger. Thumb with large elliptical subpalmar tubercle. In life, dorsal surfaces of body and limbs were scattered with low, flat tubercles. Subarticular tubercles simple, except distal tubercle on finger IV, which is bifid. Relative length of fingers $3>4>2>1$. Finger I free of webbing, formula for the other fingers II2- $3+$ III3- -2 1/2IV.

Legs smooth except proximal 2/3 of ventral surface of thigh (granular) and a few very faint, non-raised tubercles on the posterior part of tarsus. A large elliptical inner and a small round outer metatarsal tubercle. Subarticular tubercles simple, conical. Webbing formula $\mathrm{I} 1+-21 / 3 \mathrm{II} 1+-3-\mathrm{III} 1+-3-\mathrm{IV} 21 / 2-1+\mathrm{V}$. Relative length of adpressed toes $4>5 \geqslant 3>2>1$.

Colouration. In alcohol the dorsal and lateral areas of the body are dark tan. The tympanum is light brown bordered by a tan ring. There is a substantial cream subocular 


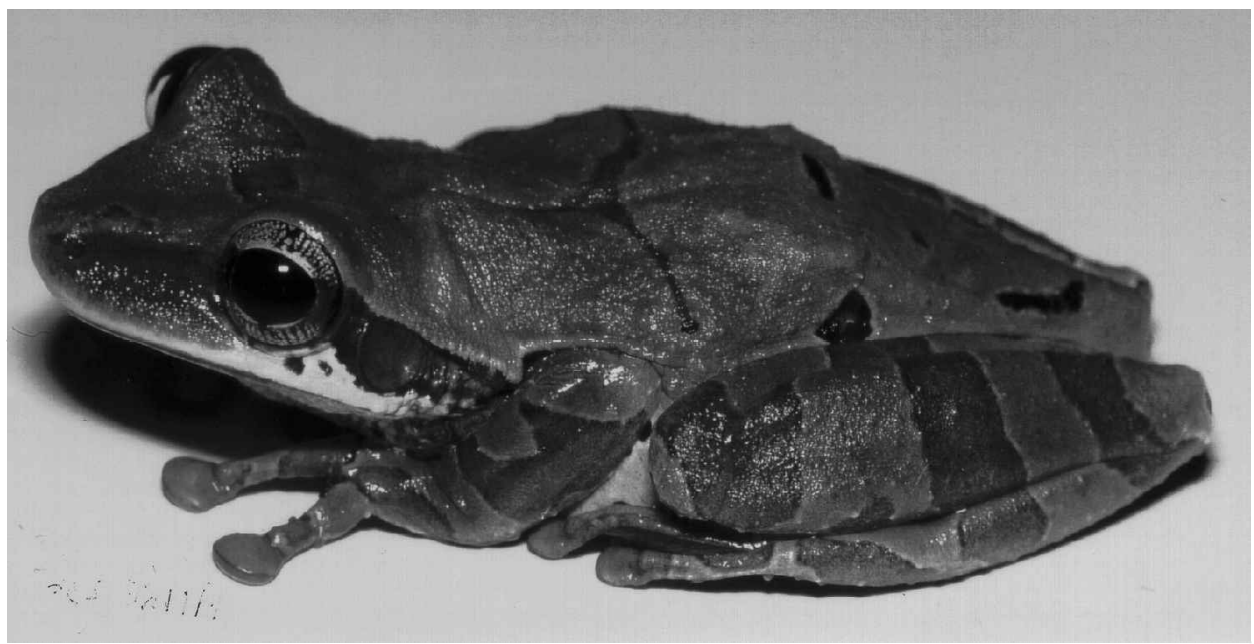

(a)

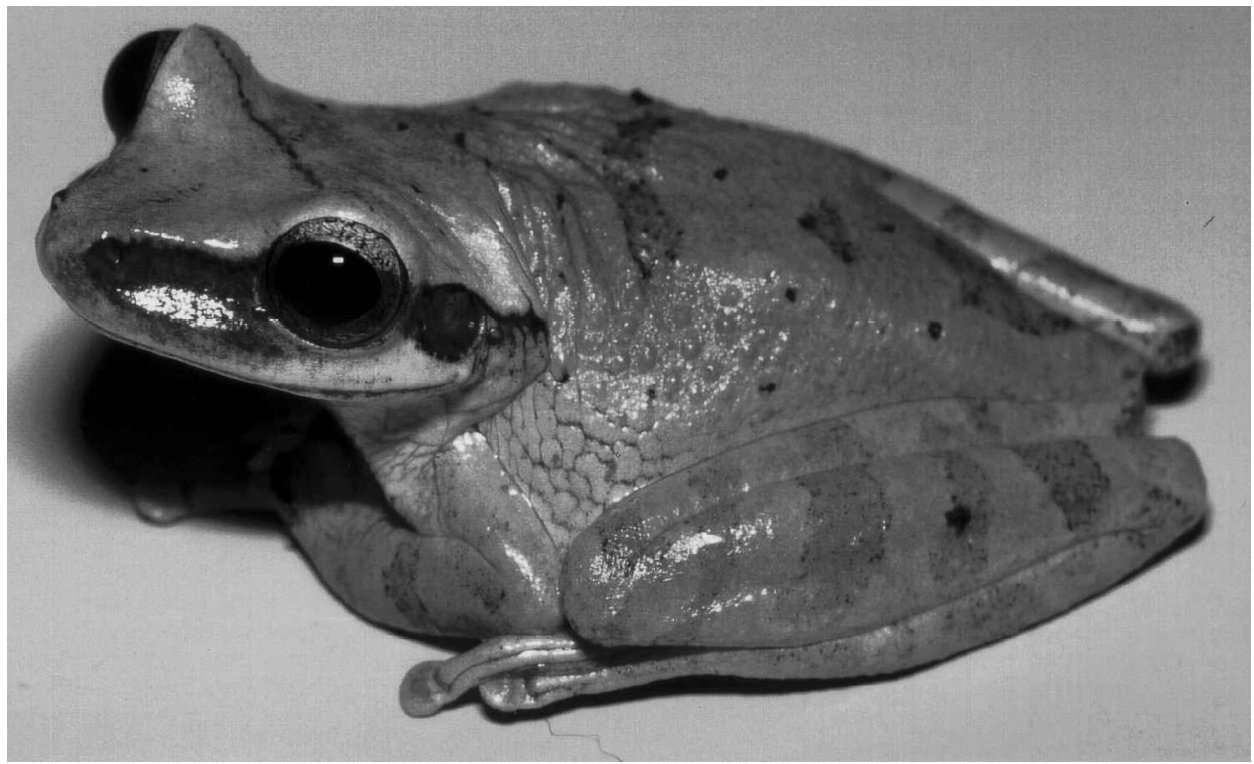

(b)

Figure 5. Similar species of Osteocephalus, syntopic with both new species in some areas. (a) O.planiceps, young female, $65 \mathrm{~mm}$, from Jatun Sacha, Ecuador; (b) O. yasuni, female, $57 \mathrm{~mm}$, from Estación Biológica Yasuní, Río Tiputini, Ecuador.

area extending posteriorly to the tympanum. Ventral and ventrolateral surfaces of the body creamy white. A narrow interrupted tan line runs around the mandible. Limbs creamy white 
ventrally, tan laterally and dorsally. Posterior surfaces of thighs light tan. An elliptical tan supraanal mark. Subanal tubercles creamy white. Bones, visible through the skin of parts of the hind legs, green.

Colours in life were principally the same, but dorsal surfaces changed from light greyish brown to dark tan, and the bars on the limbs were always darker than surrounding areas. Ventral surfaces of hands and limbs were reddish tan. The iris was golden yellow with radiating black lines and a broad dark grey horizontal bar at midlevel.

Variation. There is little variation in proportions in the type specimens, all but one were collected less than $5 \mathrm{~km}$ apart from each other. The mean value for head length/SVL is $0.352(s=0.010)$, head width/SVL $0.338(s=0.008)$, tympanum diameter/eye diameter $0.607(s=0.018)$, tibia length/SVL $0.557(s=0.037)$, foot length/SVL 0.659 $(s=0.024)$.

The dentigerous processes of prevomers reach beyond the choanae posteriorly in all specimens but SMF 78742.

Colour variation is considerable and individuals can be recognized in the field by different dorsal markings. They include irregular dark tan blotches, suffusions of dark tan, or irregular light brown spots or flecks. One specimen (not preserved) has a light brown triangle with the basis in the interorbital area pointing anteriorly (fig. 1c).

The inflated vocal sac is single, subgular, and moderately distensible. The only available male (QCAZ12556) has a smooth dorsum, lacks nuptial pads and has vocal slits lateral to the posterior third of the tongue. No wrinkled skin is visible on the throat.

Habitat. Osteocephalus deridens is an inhabitant of primary forest. At Jatun Sacha, a biological preserve with primary and secondary growth sections, none were found or heard outside undisturbed primary forest on steeply rolling hills drained by small streams adjacent to the Río Napo floodplain about $450 \mathrm{~m}$ a.s.l. (habitat E in fig. 6 of Flores and Vigle, 1994). Males were frequently heard calling on large trees at heights of 15$30 \mathrm{~m}$ where large epiphytic bromeliads were growing on branches. These bromeliads were hardly encountered at lower heights, except for the one described in the discussion. None of the specimens calling from high up could be collected. Very rarely we found single individuals, including the holotype, 0.1-4 m high on thin stems or twigs of bushes or young trees. They apparently were foraging females that were not involved in reproductive activity at that time.

Calls. Four advertisement calls recorded at $0.4 \mathrm{~m}$ distance of a male calling from a bromeliad on 14 August 1995 between $2055 \mathrm{~h}$ and $2101 \mathrm{~h}$ at $23.7^{\circ} \mathrm{C}$ have durations of $1.61-3.25 \mathrm{~s}(\bar{x}=2.40)$ and consist of $9-16$ notes $(\bar{x}=12.8)$. Note durations are $37-115 \mathrm{~ms}$ $(\bar{x}=61.1 ; n=49)$ with internote intervals of $77-200 \mathrm{~ms}(\bar{x}=142 ; n=45)$. Notes of the second half of the call are longer and can be subdivided into up to 18 pulses, the first one with a longer interpulse interval than the others, which are regular. Fundamental frequency is between 0.34 and $0.52 \mathrm{kHz}$, dominant frequency between 2.34 and $2.44 \mathrm{kHz}$ (fig. 3). The 
male was not collected. At that time we had not discovered yet that we had a new species before us.

Etymology. The specific name is the present participle of the Latin deridere (make fun of someone) in allusion to the males' calls from the treetops that sound as if they are laughing at the collectors' vain attempts to reach them.

Discussion. No direct observations on the reproductive behaviour of the species were possible, but on 6 August 1995 the senior author found a broken branch of a tree on the ground of the forest edge. A bromeliad (Aechmea zebrina or A. chantinii) $55 \mathrm{~cm}$ high and $80 \mathrm{~cm}$ in diameter was growing on it. Three leaf axils haboured Osteocephalus larvae very much reminiscent of those of the Central Amazonian O. oophagus. At night a male $O$. deridens was calling from another leaf axil of the same bromeliad. Two nights later the same male (identified by dorsal markings) was present and the larvae were filled with undamaged frog eggs. A few eggs not eaten yet were also visible in the water. During the following three nights no $O$. deridens was associated with the bromeliad, but on 12 August the same male was calling occasionally from the same leaf axil as before. The next night the male was present, and later that night a second male was in the bromeliad that left upon our disturbance. The first male was also present the following two nights. The tadpoles were getting thin and were collected on 16 August. They were raised in the laboratory with fertilized eggs of $O$. oophagus which they ingested without crushing them.

The almost continuous presence of $O$. deridens males with the tadpoles leads us to assume that they were those of $O$. deridens. The fact that they had eaten eggs indicates that $O$.deridens is a species with parental care providing the tadpoles with fertilized eggs for consumption, a behaviour that is also known in O. oophagus (Jungfer and Schiesari, 1995; Jungfer and Weygoldt, 1999). Two leftover eggs apparently of $O$. deridens found in a leaf axil on the morning of 9 August were developing and one tadpole found on 16 August was considered to be no older than one week. The female that did not return was probably eaten by a predator. Another leaf axil of the bromeliad regularly harboured several Eleutherodactylus acuminatus during the day.

Osteocephalus fuscifacies n. sp. (fig. 1d-e, 4)

Holotype. EPN-H 6657, an adult male collected by K.-H. Jungfer on 27 December 1997 at Estación Biológica Jatun Sacha, (01 ${ }^{\circ} 4^{\prime}$ S; $\left.77^{\circ} 36^{\prime} \mathrm{W}\right)$, Provincia Napo, Ecuador, $450 \mathrm{~m}$ a.s.l.

Paratypes. Seven specimens: EPN H-4774 and H-4775, adult males from Rucullacta, 2 km NNW Archidona, Provincia Napo, Ecuador, collected by A. Almendáriz; MHNG 2366.73 and 2373.91, adult males, partly dissected, from San Pablo de Kantesiya, Provincia Sucumbíos, Ecuador, collected by J. M. Touzet; ZFMK 68660 an adult female from Aliñahuí, 5 km W Ahuano, Provincia Napo, Ecuador, collected by R. Perez; QCAZ 8137, an adult male, from the Pompeya-Iro Road, 38 km southeast of Pompeya, Provincia Fran- 
cisco de Orellana, Ecuador, collected by Morley Reed; QCAZ 8806, an adult female colleced by Nestor Acosta, from the El Tena-Talag Road, $15 \mathrm{~km}$ from El Tena, Provincia Napo, Ecuador.

Diagnosis. A small to medium sized species of the genus with males known to reach $45.6 \mathrm{~mm}$ and females $53.2 \mathrm{~mm}$ SVL. Dorsum of males and females smooth. Skin on flanks smooth. Webbing on hand weak, barely or not reaching proximal level of antepenultimate subarticular tubercle on inner edge of third finger. Dorsal colour light or dark tan, with or without irregular darker or lighter tan markings. Venter dark with creamy white granules or creamy white. Light subocular spot absent. Flanks tan with or without darker or lighter markings. Dentigerous processes of prevomers angular. Dorsal roofing bones of the skull (frontoparietals, sphenethmoid, nasals) exostosed, indicating co-ossification (visible in MHNG 2366.73).

Comparisons. The lack of a light subocular area distinguishes Osteocephalus fuscifacies from most other Osteocephalus from the northwestern Amazon Basin and northern South America: There is a light subocular area in O. ayarzaguenai, O. deridens, O. elkejungingerae, O. leprieurii, O. planiceps (fig. 5a), O. sp. from Peru (Rodríguez and Duellman, 1994; Duellman and Mendelson, 1995), O. verruciger and O. yasuni (fig. 5b). Most $O$. oophagus and $O$. taurinus lack a light subocular area. Both have considerably more webbing on the hand, that reaches beyond the antepenultimate subarticular tubercle on the inner side of the third finger. Osteocephalus buckleyi and $O$. cabrerai have a light subocular area which is indistinct in some individuals. The two species also differ in having a tubercular tarsus (smooth in O. fuscifacies) and a clear or at best reticulate iris (straight rays).

Description of holotype. An adult male of $44.8 \mathrm{~mm}$ SVL. Head wider than body and about as long as wide. Head dorsally slightly concave. Canthus rostralis angular, curving. Loreal region concave. Nostrils protuberant, opening laterally. Snout truncate in lateral aspect and rounded dorsally. Dentigerous processes of prevomers in between choanae, reaching slightly posterior to choanae, in contact with each other, angular.

A dermal fold curving posterior to midlevel of eye above the tympanum and becoming indistinct posterior to it. Tympanum conspicuous, round, diameter about half of that of the eye. Axillary membrane absent. Dorsum and flanks smooth. Throat smooth. Chest, belly and ventral surfaces of thigh granular. Vent opening at upper level of thighs. No conspicuously raised subanal tubercles.

Arms smooth, except for a few flat tubercles on the distal ventrolateral edge of the forearm. Thumb with large elliptial subpalmar tubercle, nuptial pad absent. Subarticular tubercles simple, except for a bifid distal tubercle on finger IV. Relative length of fingers $3>4>2>1$. Finger I free, webbing formula II2- - 3+III3 - 3-IV.

Legs smooth with the exception of granular ventral surface of the thigh. A large elliptical inner metatarsal tubercle. Subarticular tubercles simple, conical. Webbing formula 
I1 $4 / 5-21 / 2 \mathrm{II} 1+-3 \mathrm{III} 11 / 2-3 \mathrm{IV} 21 / 2-1+\mathrm{V}$. Relative length of adpressed toes $4>5>3>2>1$.

A single tubercle on the posterior edge of the canthus rostralis apparently was caused by a parasite.

Colouration. In preservative all dorsal and lateral surfaces dark tan. Ground colour of venter light tan with scattered creamy white granules. Throat tan suffused with white, becoming darker posterolaterally. Circumanal area as tan as surrounding skin. Limbs dark tan dorsally and laterally, somewhat lighter ventrally. A few irregular bars darker than ground colour visible dorsally on tibiae. Webbing dark tan.

In life, all shades of tan were lighter than in preservative. Tibiofibula green (not visible in alcohol). The iris was golden with black radiating lines and a dark grey horizontal bar at midlevel.

Variation. Proportions of the eight specimens of the type series are as follows (mean values and standard deviation): Head length/SVL $0.362(s=0.009)$, head width/SVL $0.358(s=0.017)$, tympanum diameter/eye diameter $(n=7) 0.513(s=0.222)$, tibia length/SVL $0.522(s=0.028)$, foot length/SVL $0.626(s=0.094)$.

The single female (ZFMK 68660) differs markedly in having the proportionately smallest tympanum. Considerable differences among the type series also exist in tibia and foot lengths, which are shortest in the holotype. Webbing on the hand reaches the proximal level of the antepenultimate subarticular tubercle on inner edge of third finger in the holotype and the two specimens from San Pablo de Kantesiya (MHNG 2366.73 and 2373.91), but not in the others (formula: 3 1/4-3 1/5).

The ground colour of all specimens is tan. All have bars on the limbs and four of them (EPN H-4774 and H-4775, MHNG 2366.73 and 2373.91) have irregular darker tan transverse bars or blotches on the dorsum. ZFMK 68660 has irregular dark tan transverse lines as well as irregular light spots dorsally. Two living females from Selva Viva, a protected forest about $18 \mathrm{~km}$ (by road) W of Jatun Sacha, and one male from Yasuní, are uniform tan dorsally. Male QCAZ 8806 has a darker interorbital band delimited by a white margin. Posterodorsally there is a dark tan area with a few irregular light spots, and the sacral area is light tan with some irregular dark tan spots.

ZFMK 68660, MHNG 2366.73 and 2373.91, QCAZ 8137 and 8806 are light tan ventrally with creamy white granules; the throat is light suffused with tan spots. The two specimens from Rucullacta (EPN H-4774 and 4775) are completely creamy white ventrally with only a few inconspicuous tan spots on the anterior portion of the throat.

In life, the tibiofibulae were recorded to be light green in the holotype and two specimens from Selva Viva. No green is visible in any preserved specimen, except in ZFMK 68660 and QCAZ 8137.

The vocal sac of a calling specimen was single, subgular and moderately distensible. No wrinkled skin or skin folds are visible in males of the type series. 
Habitat and natural history. Specimens of $O$. fuscifacies were found only occasionally on trees or bushes up to $6 \mathrm{~m}$ high in primary forest at Jatun Sacha, Selva Viva (about $18 \mathrm{~km}$ W of Jatun Sacha), and km 38 of the Pompeya-Iro Road in the same habitat as O.deridens. Male QCAZ 8806 from $15 \mathrm{~km}$ from El Tena at the El Tena-Talag Road was perched on a branch $50 \mathrm{~cm}$ high, next to a stream (Nestor Acosta's field notes). At Yasuní, QCAZ 8137 was calling from a bromeliad $2.5 \mathrm{~m}$ high in terra firme forest at night in January 1995 (Morley Reed's field notes). The latter specimen and a captive male that was calling from a bromeliad, although open water was available, are the only indications that spawning might occur in bromeliads as well.

Calls. The holotype was kept in a terrarium for some time and called from a bromeliad there. A call consisted of a short single note emitted infrequently. No recordings are available.

Etymology. The specific name fuscifacies is a compound of the Latin fuscus ( $\tan$ ) and facies (face) referring to the uniform tan loreal region and the lack of a light subocular spot in this species of Osteocephalus.

Distribution and sympatry. So far, $O$. deridens and $O$. fuscifacies are only known from intermediate elevations between 250 and $600 \mathrm{~m}$ a.s.l. of the Río Napo drainage in the provinces of Napo, Francisco de Orellana and Sucumbíos, Ecuador. All localities are in the Wet Tropical Forest vegetation formation (Holdridge, 1964). Most likely, the distribution of both species is wider than presently known and more specimens are hidden in collections under other names, as was the case in O.planiceps, a widespead species in Amazonian Ecuador and until recently confused with $O$. taurinus.

At Jatun Sacha, both new species were found in sympatry with $O$. buckleyi, O. cabrerai and $O$. planiceps. Aliñahuí is a privately owned hacienda that accommodates ecotourists. There are primary forest remnants adjacent to the Jatun Sacha reserve. Selva Viva is a protected forest on hilly ground about 400 to $600 \mathrm{~m}$ a.s.l. roughly $18 \mathrm{~km}$ (by road) from Jatun Sacha downstream Río Napo. Osteocephalus deridens was only heard there. Other species present were $O$. buckleyi, O. cabrerai, O. fuscifacies, O. leprieurii, and O. planiceps.

The locality at the Pompeya-Iro Road, $38 \mathrm{~km}$ southeast of Pompeya, is at the north border of Yasuní National Park at an altitude of $250 \mathrm{~m}$ a.s.l. The Yasuní region is covered by primary terra firme, varzea, and seasonally flooded forests. At Yasuní, O. fuscifacies and $O$. deridens are sympatric with $O$. buckleyi, O. cabrerai, O. planiceps, O. taurinus and O. yasuni. The locality on the El Tena-Talag Road is $550 \mathrm{~m}$ a.s.1.

With the exception of $O$. buckleyi and $O$. cabrerai, which inhabit both primary and secondary forest at Jatun Sacha, and of $O$. leprieurii, which was found at forest edge and in primary forest, all species are exclusively primary forest dwellers. 
Acknowledgements. KHJ's work was supported by a grant of FWF Project P 11565-Bio "Biology of Amphibians and Reptiles of the Rainforest Canopy" to Walter Hödl, principal investigator. It also covered the costs of the colour plate. We would like to thank Wolfgang Böhme (ZFMK), Luis Coloma (QCAZ), Gunther Köhler (SMF) and Jean Mariaux (MHNG) for the loan of specimens and working facilities at their institutions. KHJ would like to express his thanks to Oliver Piskurek and Steffen Reichle and RS to Gunther Köhler for their invaluable help in the field. Ronald Heyer, Gunther Köhler and an anonymous reviewer made helpful comments on the manuscript. Collecting permits were issued by INEFAN (Ing. Arturo Ponce S.).

\section{References}

Coloma, L.C. (1991): Anfibios del Ecuador: Lista de especies, ubicación altitudinal y referencias bibliográficas. Rep. Téc. EcoCiencia 2: 1-46.

Duellman, W.E. (1970): Hylid frogs of Middle America. Monogr. Mus. Nat. Hist. Univ. Kansas 1: 1-753.

Duellman, W.E., Hoogmoed, M.S. (1992): Some hylid frogs from the Guiana Highlands, northeastern South America: new species, distributional records, and a generic reallocation. Occ. Pap. Mus. Nat. Hist. Univ. Kansas 147: 1-21.

Duellman, W.E., Mendelson, J.R. (1995): Amphibians and reptiles from northern Departamento Loreto, Peru: Taxonomy and biogeography. Univ. Kansas Sci. Bull. 55: 329-376.

Flores, G., Vigle, G.O. (1994): A new species of Eleutherodactylus (Anura: Leptodactylidae) from the lowland rainforests of Amazonian Ecuador, with notes on the Eleutherodactylus frater assembly. J. Herpetol. 28: 416424.

Gorsula [sic!], S., Señaris, C. (1996): Una nueva especie de Osteocephalus (Anura: Hylidae) de la Gran Sabana, Venezuela. Acta Biol. Venez. 16: 19-22.

Heyer, W.R., Rand, A.S., da Cruz, C.A.G., Peixoto, O.L., Nelson, C.E.(1990 Frogs of Boracéia. Arq. Zool. Mus. Zool. Univ. São Paulo 31: 231-410.

Holdridge, L.R. (1964): Life Zone Ecology. San José, Tropical Science Center.

Jungfer, K.-H., Schiesari, L.C. (1995): Description of a Central Amazonian and Guianan tree frog, genus Osteocephalus (Anura, Hylidae), with oophagous tadpoles. Alytes 13: 1-13.

Jungfer, K.-H., Weygoldt, P. (1999): Biparental care in the tadpole-feeding Amazonian treefrog Osteocephalus oophagus. Amphibia-Reptilia 20: 235-249.

Myers, C.W., Duellman, W.E. (1982): A new species of Hyla from Cerro Colorado, and other tree frog records and geographical notes from western Panama. Amer. Mus. Novit. 2752: 1-32.

Rodríguez, L.O., Duellman, W.E. (1994): Guide to the frogs of the Iquitos region, Amazonian Peru. Univ. Kansas Nat. Hist. Mus. Spec. Publ. 22: 1-80, plates 1-12.

Ron, S. (1998): Biogeographic area relationships of lowland Neotropical rainforests based on cladistic analysis of anurans. M. A. Thesis, University of Kansas, Lawrence.

Ron, S., Pramuk, J.B. (1999): A new species of Osteocephalus (Anura: Hylidae) from Amazonian Ecuador and Peru. Herpetologica 55: 433-446.

Savage, J.M., Heyer, W.R. (1967): Variation and distribution in the tree-frog genus Phyllomedusa in Costa Rica, Central America. Beitr. Neotrop. Fauna 5: 111-131.

Trueb, L., Duellman, W.E. (1971): A synopsis of Neotropical hylid frogs, genus Osteocephalus. Occ. Pap. Mus. Nat. Hist. Univ. Kansas 1: 1-47.

Received: December 22, 1998. Accepted: January 7, 2000. 
Copyright of Amphibia-Reptilia is the property of VSP International Science Publishers and its content may not be copied or emailed to multiple sites or posted to a listserv without the copyright holder's express written permission. However, users may print, download, or email articles for individual use. 